\title{
Commentary
}

\section{Locating postcolonialism}

\author{
Mary Gilmartin* and Lawrence D Berg** \\ *School of Geography, Planning and Environmental Policy, University College Dublin, Belfield, \\ Dublin 4, Ireland \\ Email: mary.gilmartin@ucd.ie \\ ${ }^{* *}$ Community, Culture and Global Studies, University of British Columbia, Kelowna, BC, Canada V1V 1V7
}

Revised manuscript received 17 November 2006

\section{Introduction}

As geographers both living through, and working on, issues of colonialism in former British colonies, the writings that emanated from anti-colonial movements around the world continue to inspire and move us. From Fanon to Césaire, from Senghor to Cabral to Achebe (see, for example, Fanon 1963 1986; Senghor 1965; Césaire 1972; Achebe 1975; Cabral 1980), these writings are influential partly because they are grounded in experiences of oppression, but also because they contain alternative visions, alternative understandings of how the world could be better. Their successors are to be found today in different guises, yet writers like Marcos in Chiapas, or Arundhati Roy in India, continue to rail against injustice, and to use the power of language to convince us that other worlds are possible (see, for example, Roy 19992002 2004; Marcos 2005).

Academic postcolonial theory, however, especially as enacted in Anglo-American Geography generally, and 'British' Geography specifically, is less likely to refer to the writers and theorists of anti-colonial struggles, and more likely to refer to a triad of postcolonial theorists: Edward Said, Homi Bhabha and Gayatri Spivak. Said helped many geographers understand the relationship between colonial projects and imaginary, metaphorical and material geographies (e.g. Said 1979 1994). Bhabha gave geographers a more nuanced understanding of the hybrid and unstable character of colonialism (e.g. Bhabha 1994). Spivak, among other things, helped some geographers to understand some of the problematic neo-colonial impulses of postcolonial theory (Spivak 1988). In this early work,
Spivak asked if postcolonial studies can be seen to problematically reinscribe neo-colonial imperatives, and she answered this question in the affirmative.

The aim of this paper is not to critique Said, Bhabha or Spivak, nor is it to deny the importance of the extant body of work in postcolonial geography. Rather, what we want to do is point to the limited ways in which many (but not all) British geographers have appropriated postcolonial theory in the construction of 'postcolonial geographies'. In doing so, we want to suggest that much of what passes for postcolonial theory in British geography reinforces new forms of colonial epistemologies and colonial hierarchies, while destabilizing their older forms. This Commentary is thus an attempt, in part at least, to revisit and extend some of the issues that Spivak (1988) examined in her work of almost two decades ago.

It is important to stress that we are not dismissive of postcolonial theory. Rather, it is because we embrace the possibilities suggested by a range of anti-colonial and postcolonial writers that we want to see an expansive notion of postcolonial geography. For us, postcolonialism offers a radical and productive critique of how we think about and do geography. At the same time, we want to suggest that there is a significant difference to be found between 'anticolonial' and 'postcolonial' geographies. Writing from the ostensible 'margins' of former British colonies, we find our own experiences as both colonizers and colonized resonating more with anti-colonialism than with postcolonialism. At the same time, we are reminded by Derek Gregory of the powerful potential that postcolonialism has to help us critically to understand the colonial present. But to do so, 
postcolonial critique must not only counter amnesiac histories of colonialism but also stage stage 'a return of the repressed' to resist the seductions of nostalgic histories of colonialism. (Gregory 2004, 9; original emphasis)

\section{How geographers 'do' postcolonialism: the problems with postcolonial geographies}

When did geography 'discover' postcolonialism? We're going to date this to the early 1990s, and the publication of a range of texts that started to engage with geography's colonial and imperial history. In doing so, many authors were developing themes that had been raised earlier - in articles such as 'The New Geography and the New Imperialism' by Brian Hudson (1977; written while he was working in the West Indies), or in the work of Keith Buchanan (a geographer based primarily in New Zealand who was recently rehabilitated by Power and Sidaway 2004) - but that had been ignored, marginalized or discounted in intervening periods. In the early 1990s, however, authors and editors such as David Livingstone (1992), Jim Blaut (1993), Anne Godlewska and Neil Smith (1994), Alison Blunt and Gillian Rose (1994) and Jane Jacobs (1996), to name just a few, brought the need for a reappraisal of geography's history, and in particular its colonial complicity, to the forefront.

The grounds for postcolonial engagement in geography were set by these texts, in conjunction with the work of earlier writers like Said. The kind of work undertaken by these geographers can be thought of as falling within what has been termed the 'critical colonial histories' approach (King 2003, 390). In this regard, they have been concerned with using colonial discourse analysis to interrogate particular colonial archives - usually centred on other regions and other times. A particular interest is nineteenth-century British colonialism, increasingly understood through what we might call a metropolitan colonial lens. In this way, the focus is on British colonial institutions and colonialists as constituted in a faraway past (for examples, see Blunt 1994; Gregory 1994; Kearns 1997; Phillips 1997; Driver 1999; McEwan 2000; Lester 2001).

Another strand of research can be identified, namely that concerned with addressing contemporary colonial situations in supposedly postcolonial states, exemplified by works by authors such as Jane Jacobs in Edge of empire (Jacobs 1996), Daniel Clayton in
Islands of truth (Clayton 2000), Cole Harris in Making native space (Harris 2002) and Derek Gregory in The colonial present (Gregory 2004). Interestingly, all of these geographers' works are marked by long periods of living in former colonies, and we suggest that such specific geographies of embodied practice (after Simonsen 2003) have material implications for the way these writers understand the (post)colonial condition. Indeed, Derek Gregory (1994) acknowledged in an earlier work that his move to western Canada made an important difference to his understanding of The geographical imagination, since it forced him to consider colonialism and the colonial legacy 'not as purely intellectual concerns but as matters of everyday practice' (Gregory 1994, ix).

It is important to note, however, that the two approaches we discuss above have not been given equal weight within geography. Undoubtedly geographers who are based in former colonies, as Jacobs was at the time, have sought to show how the cultural politics of colonialism and postcolonialism continue to be articulated in the present' (Jacobs, in King 2003, 390). Ironically, such work has been celebrated by 'metropolitan' postcolonial geographers in a way that effaces direct anti-colonial critique while it bolsters the more tentative critiques that inhere in British postcolonialism. As Clive Barnett perceptively commented 10 years ago, theoretically inclined critical geographers have been 'busy grabbing for their share of colonial guilt', and that the obsession with geography's past acts as a way of 'avoiding looking in the most obvious places' and interrogating the discipline as it stands today (Barnett 1995, 418-19).

'Modern colonialism won its great victories', according to Ashis Nandy, 'through its ability to create secular hierarchies' (1988, ix). This, then, is the first key difficulty with contemporary British postcolonial geographies: the creation of a hierarchy that prioritizes the past over the present, and the faraway over the nearby. In other words, there is a tendency in British postcolonial geography that reinforces the hierarchical thinking that underpins colonialism. The second key difficulty is interrelated: it concerns the uneven production of postcolonial theory in geography. Writing in the 1950s, Octave Mannoni claimed that 'a colonial situation is created ... the very instant a white man ... derives from his position . . . a feeling of his own superiority' (Mannoni 1956, 18). Within geography, the colonial situation is reiterated as 'authorities' in the Anglo core define the important debates and central positions of 'Geography'. 
Geographers from the peripheries may be allowed to participate, but not to set the agenda (for extended critiques of these kinds of colonizing theories see Minca 2000; Robinson 2003; Paasi 2005). As an example, Lawrence has written of the colonial situation in relation to the marginalization of postcolonial geographers from Australia and Aotearoa/ New Zealand. For many years involved in the fight to de-colonize both the epistemological and the 'real' material spaces of colonial societies, these geographers are often made to feel not quite postcolonial enough in settings dominated by British postcolonial geographers (Berg 2002). Similarly, Jenny Robinson has written of the 'perilously little theoretical or generalisable learning' that Western scholars have derived from South Africa (Robinson 2003, 284. See also Minca 2000; Clayton 2003; Paasi 2005).

We wish to illustrate these two key critiques with the example of a very specific elision in the production of (post)colonial space in British academic geography: an elision in terms of the use of postcolonial theory to interrogate both temporality and spatiality. In this regard, we are interested in making more visible the focus on faraway pasts and geographically distant spaces as the spatio-temporal containers of 'postcolonial geographies'. In this regard, we suggest that a selective focus on nineteenthcentury British colonialism in its former imperial possessions tends to elide present-day colonial relations. We take as an exemplary case the question of Ireland and its problematic relations with Britain.

In this respect, many postcolonial geographers have been remarkably slow to engage with the question of Ireland - a question that postcolonial literary theorists have been dealing with for many years (see, for example, Lloyd 1993 1999; Kiberd 1995; Gibbons 1996; Carroll and King 2003). Given geographers' sense of their academic identity as indelibly linked to the materiality of place, of being rooted in 'real places', this lacuna is doubly problematic. Ireland was, many argue, Britain's first colony, as well as the first British colony to achieve some form of independence. It was the place where many British colonial practices were first tested, such as the implementation of a national education system. The long-term effects of settler colonialism are still evident in political conflict in Northern Ireland, which in turn has had a negative effect on the status of many Irish migrants living in Britain. Ireland is thus central to the construction of British identity and to British colonial identity: 'if Ireland had never existed, the British would have invented it' (Kiberd
1995, 9). Yet discussions of Ireland or the use of Irish postcolonial theory in postcolonial geographies emanating from Britain are extremely rare. There are some exceptions, such as the work of Catherine Nash (Nash 19941997 1999), and tentative allusions to Ireland in recent works by Alison Blunt and Jane Wills, and James Sidaway. These are, however, limited in their fluency and engagement. Blunt and Wills devote four pages to their discussion of the Irish famine (Blunt and Wills 2000, 198-201), while Sidaway, in a key article on postcolonial geographies, constantly defers a discussion of Northern Ireland in the context of post/colonialism (Sidaway 2000). In a revised version of the article, Sidaway attempts to re-engage with the question of Northern Ireland. He points out that the status of . . European states that have succeeded empire in the twentieth century (such as Albania and Ireland) raises some further problematics', but ultimately disengages again from Northern Ireland with an 'in passing' comment that 'much of Europe has, at one time or another, been subject to imperial rule' (Sidaway 2002, 15). While this revision highlights Sidaway's awareness of the difficulties with his first elucidation of the Irish question, it also points to the problems many postcolonial geographers have in engaging with nearby colonialism and its aftermath. As British postcolonial geography gets defined for a global audience, the specificities of its production - both spatially and theoretically - get obscured.

In using these examples, we are not arguing that all British postcolonial geographers should be writing about Ireland. Neither are we claiming that metropolitan geographers should not be writing about postcolonialism. Instead, we are arguing against an undifferentiated British postcolonial geography that fails to engage with the specificity of geographical contexts and that, in doing so, recasts what Mannoni (1956) described as the colonial situation. And we are arguing for a postcolonial geography that engages with contemporary situations in a way that challenges, rather than reinforces, colonial hierarchies.

We recognize that this represents a difficult balance, that of speaking to colonialism and to postcolonial theory as global, but also of recognizing the specificities of colonial and postcolonial experiences. This suggests the need to engage in a double movement: the globalizing tendencies of theory production in academic geography need to be tempered by the specific geographies of colonialism, imperialism and postcolonialism. This double movement is important because it helps us to remember, as Mamdani 
pointed out, 'decolonization in one sphere of life does not necessarily and automatically lead to decolonization in other spheres' (Mamdani 2001, xiv).

\section{Alternative postcolonial geographies}

Hardt and Negri, in Empire, write that postcolonial theorists 'combat the remnants of colonialist thinking' (2000, 137). Through the use of postcolonial theory within geography, many British geographers have fallen into the trap that Anne McClintock identified over a decade ago: of reorienting the globe around a new binary opposition, that of colonial and postcolonial, of centre and periphery, of past and present, of in Here and out There. While the new historiographies that are being written as a result of geography's engagement with postcolonial theory are undoubtedly interesting and provocative, they are neither a sufficient nor a particularly equitable application of postcolonial theory within geography. In broad terms, postcolonial theory suggests the possibility of a new epistemology within geography, even though geographers working with postcolonial theories are slow to embrace this possibility, preferring instead to fall back into now familiar discursive strategies, particularly in relation to colonial histories. As a consequence, British postcolonial geography is dominated by critiques of the discursive construction of historical colonialism, rather than focusing on the aftermath or continuation of colonialism. This effective hijacking of the postcolonial within geography means that it loses theoretical force, becomes one of a long list of 'posts' that often alienate geographers who might like to, or already do, engage with the challenges posed by postcolonialism to the ways in which we construct knowledge. We should, after all, aim to move away from the paradox wryly observed by Marc Ferro, when he commented that 'the European historical memory has retained for itself one last privilege: that of painting its own misdeeds in dark colours and evaluating them on its own terms' (Ferro 1997, vii).

\section{Acknowledgements}

A version of this paper was originally presented in a session on 'Postcolonial Geographies' at the 2005 Conference of Irish Geographers, Galway, Ireland. We are grateful to colleagues at that conference who provided helpful comments on this earlier version. We also thank Alastair Bonnett and two anonymous referees for their helpful comments on the penultimate draft of this essay.

\section{References}

Achebe C 1975 Morning yet on creation day: essays Heinemann, London

Barnett C 1995 Awakening the dead: who needs the history of geography? Transactions of the Institute of British Geographers 20 417-19

Berg L D 2002 (Some) spaces of critical geography in Rodgers $\mathbf{A}$ and Viles $\mathbf{H}$ eds The student's guide to geography 2nd edn Blackwell, Oxford 305-11

Bhabha H 1994 The location of culture Routledge, London

Blaut J M 1993 The colonizer's model of the world: geographical diffusionism and eurocentric history Guilford Press, New York

Blunt A 1994 Travel, gender and imperialism: Mary Kingsley and West Africa Guilford Press, New York

Blunt A and Rose G 1994 Writing women and space: colonial and postcolonial geographies Guilford Press, New York

Blunt A and Wills J 2000 Dissident geographies: an introduction to radical ideas and practices Prentice Hall, Harlow

Cabral A 1980 Unity and struggle: speeches and writings Heinemann, London

Carroll C and King P eds 2003 Ireland and postcolonial theory Cork University Press, Cork

Césaire A 1972 Discourse on colonialism Monthly Review Press, London

Clayton D 2000 Island of truth: the imperial fashioning of Vancouver Island UBC, Vancouver

Clayton D 2003 Critical imperial and colonial geographies in Anderson K, Domosh M, Pile S and Thrift N eds Handbook of cultural geography Sage, London 354-68

Driver F 1999 Geography militant: cultures of exploration in the age of empire Blackwell, Oxford

Fanon F 1963 The wretched of the earth Grove Press, New York

Fanon F 1986 Black skin, white masks Pluto Press, London

Ferro M 1997 Colonization: a global history Routledge, London

Gibbons L 1996 Transformations in Irish culture Cork University Press, Cork

Godlewska A and Smith N eds 1994 Geography and empire Blackwell, Oxford

Gregory D 1994 Geographical imaginations Blackwell, Oxford

Gregory D 2004 The colonial present Blackwell, Oxford

Hardt M and Negri A 2000 Empire Harvard University Press, Cambridge MA

Harris R C 2002 Making native space University of British Columbia Press, Vancouver

Hudson B 1977 The new geography and the new imperialism: 1870-1918 Antipode 9 12-19

Jacobs J M 1996 Edge of empire: postcolonialism and the city Routledge, London

Kearns G 1997 The imperial subject: geography and travel on the work of Mary Kingsley and Halford Mackinder Transactions of the Institute of British Geographers 22 450-72 


\section{Commentary}

Kiberd D 1995 Inventing Ireland: the literature of the modern nation Harvard University Press, Cambridge MA

King A 2003 Cultures and spaces of postcolonial knowledges in Anderson K, Domosh M, Pile $\mathbf{S}$ and Thrift $\mathbf{N}$ eds Handbook of cultural geography Sage, London 381-97

Lester A 2001 Imperial networks: creating identities in nineteenth-century South Africa and Britain Routledge, London

Livingstone D 1992 The geographical tradition: episodes in the history of a contested tradition Blackwell, Oxford

Lloyd D 1993 Anomalous states: Irish writing and the postcolonial moment Duke University Press, Durham NC

Lloyd D 1999 Ireland after history Cork University Press, Cork

Mamdani M 2001 When victims become killers: colonialism, nativism, and the genocide in Rwanda Princeton University Press, Princeton NJ

Mannoni O 1956 Prospero and Caliban: the psychology of colonization Methuen \& Co, London

Marcos 2005 Writings of Subcomandante Marcos of the EZLN (http://flag.blackened.net/revolt/mexico/marcos_index.html) Accessed 1 October 2005

McEwan C 2000 Gender, geography and empire: Victorian women travellers in West Africa Ashgate, Aldershot

Minca C 2000 Venetian geographical praxis Environment and Planning D: Society and Space 18 285-9

Nandy A 1988 The intimate enemy: loss and recovery of self under colonialism Oxford University Press, Oxford

Nash C 1994 Re-mapping the body/land: new cartographies of identity by Irish women artists in Blunt $\mathbf{A}$ and Rose $\mathbf{G}$ eds Writing women and space Guildford Press, London 22750

Nash C 1997 Embodied Irishness: gender, sexuality and Irish identity in Graham B ed In search of Ireland Routledge, London 108-27

Nash C 1999 Irish placenames: post-colonial locations Transactions of the Institute of British Geographers 24 457-80

Paasi A 2005 Globalisation, academic capitalism, and the uneven geographies of international journal publishing spaces Environment and Planning A 38 769-89

Phillips R 1997 Mapping men and empire: a geography of adventure Routledge, London

Power M and Sidaway J 2004 The degeneration of tropical geography Annals of the Association of American Geographers 94 585-601

Robinson J 2003 Postcolonialising geography: tactics and pitfalls Singapore Journal of Tropical Geography 24 273-89

Roy A 1999 The cost of living Flamingo, London

Roy A 2002 The algebra of infinite justice Flamingo, London

Roy A 2004 The ordinary person's guide to empire Flamingo, London

Said E 1979 Orientalism Vintage, New York

Said E 1994 Culture and imperialism Vintage, New York

Senghor L S 1965 Poetry and prose Oxford University Press, London

Sidaway J 2000 Postcolonial geographies: an exploratory essay Progress in Human Geography 24 591-612

Sidaway J 2002 Postcolonial geographies: survey-explorereview in Blunt A and McEwan C eds Postcolonial geographies Continuum, New York 11-28

Simonsen K 2003 The embodied city: from bodily practice to urban life in Öhman J and Simonsen K eds Voices from the North Ashgate, Aldershot 157-72

Spivak G C 1988 Can the subaltern speak? in Nelson C and Grossberg L eds Marxism and the interpretation of culture University of Illinois Press, Urbana IL 271-313 